of the basin, and there are also graphs of the normal monthly rainfall and number of rainy days for selected stations in addition to the lists of these facts for each station where available. The volume concludes with a bibliography and a detailed index to stations.

\section{Public Health in Costa Rica}

The March issue of the Boletin de la Oficina Sanitaria Panamericana contains an article on this subject by the President, Dr. Rafael A. Calderon Guardia. The following details are of interest. The birth-rate for 1941 was 42.9 (slight increase) and the death-rate 17 per 1,000 . The death-rate for children under one year fell from 132.4 per 1,000 in 1940 to 123.5 in 1941 . The services for pre-school and school children have been extended, 11,074 children having been attended by medical men and 18,130 by dentists. During 1941 a section was formed to provide shoes for school children, one of the most important measures for protection of their health. For the first time a travelling exhibition for health education was started and circulated throughout the country. The Tuberculosis Division continued its work of systematic examination of the employees of the various divisions of the department of public health. Of 24,322 persons examined for venereal diseases, 4,242 were found to be infected and 1,305 were classified as doubtful. Soil sanitation was carried out intensively. The anti-malarial campaign was carried on according to the plans of the Rockefeller Foundation. New buildings have been constructed for health units in different parts of the country.

\section{Undulant Fever in Chile}

IN a recent article (Bol. Of. San. Panamericana, 22, 400 ; 1943) Enrique Onetto, director of the Diagnostic Laboratory of the Chile Bacteriological Institute, discusses the historical aspects and present state of undulant fever in Chile. The disease was first diagnosed in that country in 1931, when it was found near Santiago, and in 1940 a new focus was discovered in the northern part of the country. The commonest variety is Brucella melitensis, though Br. abortus has also been isolated in cattle. The infection is most prevalent in the southern part of Chile. Since 1936 the Huddleson reaction has been performed systematically on all the sera received for the Widal reaction. In 1936 also the Department of Public Health created a permanent commission for the study of brucellosis composed of medical men, bacteriologists and veterinarians.

\section{Rudolf Boehm (1844-1926)}

Prof. Rudolf BoEHM, a prominent pharmacologist, was born on May 19, 1844, at Nördlingen in Bavaria, the son of a medical man. He received his medical education at Munich, Würzburg and Leipzig, where he qualified in 1867. He first devoted himself to psychiatry, serving as assistant in the psychiatric clinic at Würzburg. Afterwards he took up the study of pharmacology at Leipzig and commenced his important studies on cardiac poisons. In 1871 he was appointed assistant at the Physiological Institute at Würzburg under A. Fick, and in the following year succeeded Schmiedeberg in the chair of pharmacology at Dorpat, eventually holding the corresponding chairs at Marburg and Leipzig. He died on August 16, 1926, in Upper Bavaria. Besides numerous pharmacological articles on veratrin, aconitin, arsenic, digitalis, and curare, and physiological investigations, especially on carbohydrate metabolism, he was the author of a "Lehrbuch der allgemeinen und speziellen Arzneiverordnungslehre" in 1884, the third edition appearing in 1903 .

\section{Announcements}

SrR Lewis Fermor, formerly director of the Geological Survey of India, has been awarded the P. N. Bose Memorial Medal for 1943 of the Royal Asiatic Society of Bengal, in recognition of his "conspicuously important researches on the Archæan Rocks of India".

Prof. C. M. Yonge, professor of zoology in the University of Bristol, has been appointed regius professor in the University of Glasgow, in succession to Prof. E. Hindle, who has become scientific director of the Zoological Society of London.

THE Rockefeller Foundation has made a grant of 15,000 rupees (about $£ 1,100$ ) to the National Institute of Sciences of India, to give assistance in the publication of scientific papers in Indian journals. This grant is similar in character to that which has been made by the Foundation to the Royal Society annually for some years, for assisting the publication of scientific papers in Great Britain.

THE following appointments in the Colonial Service have recently been made: $O$. J. Voelcker (senior botanist, Nigeria), seconded to Gold Coast for duty in connexion with cocoa diseases; D. Stevenson (senior assistant conservator of forests, Gold Coast), conservator of forests, Gold Coast; J. A. Wills (senior assistant conservator of forests, Gold Coast), conservator of forests, Gold Coast; C. M. Tattam (senior geologist, Nigeria), deputy director of geological surveys, Nigeria.

BY arrangement with the University of Cambridge, the Medical Research Council has established a Unit for Research in Applied Psychology at Cambridge. The Unit is located in the University Psychological Laboratory, the head of which is Prof. F. C. Bartlett. Dr. K. J. W. Craik has been appointed to the Council's staff as director of the Unit, and will have the collaboration or assistance of other workers there in the Council's service. The members of the Unit will undertake work elsewhere than at Cambridge when required, including investigations within the field of the Council's Industrial Health Research Board.

THE Institution of Chemical Engineers and the Institute of Physics announce a joint conference on "Instruments for the Automatic Controlling and Recording of Chemical and Other Processes". Provisional arrangements have been made for the conference to take place in London on September 22 and 23. The purpose of the conference is to promote the interchange of knowledge and experience between those employing automatic controllers and recorders in different fields and to encourage collaboration between physicists and chemical engineers. The conference will be open to all interested without charge. Further particulars will be sent, in August, to those sending a request for them to the Organizing Secretary, Joint Conference, c/o The Institution of Chemical Engineers, 56 Victoria Street, London, S.W.1. 